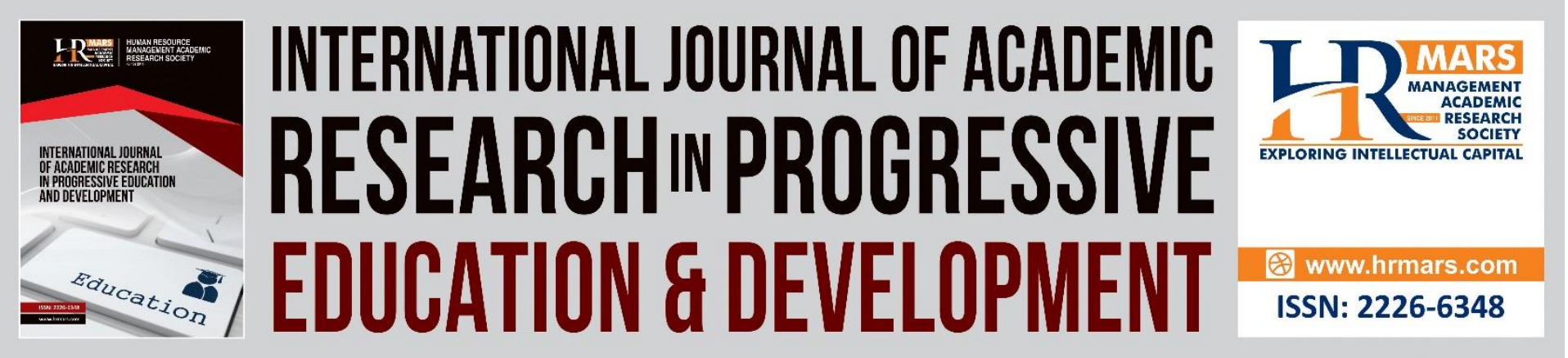

\title{
Evaluation of Academic Staff Development Practices Outcomes on Job Performance in Selected Public Universities in Kenya
}

Jane Irene A. Dawo, Simatwa Enose, M. W., Okwatch Tony, O.

To Link this Article: http://dx.doi.org/10.6007/IJARPED/v1-i4/11965

DOI: 10.6007/IJARPED/v1-i4/11965

Received: 11 September 2012, Revised: 13 October 2012, Accepted: 19 October 2012

Published Online: 21 November 2012

In-Text Citation: (Dawo et al., 2012)

To Cite this Article: Dawo, J. I. A., Simatwa Enose, M. W., \& Okwatch Tony, O. (2012). Evaluation of Academic Staff Development Practices Outcomes on Job Performance in Selected Public Universities in Kenya. International Journal of Academic Research in Progressive Education and Development, 1(4), 24-33.

Copyright: (c) 2012 The Author(s)

Published by Human Resource Management Academic Research Society (www.hrmars.com)

This article is published under the Creative Commons Attribution (CC BY 4.0) license. Anyone may reproduce, distribute, translate and create derivative works of this article (for both commercial and non-commercial purposes), subject to full attribution to the original publication and authors. The full terms of this license may be seen at: http://creativecommons.org/licences/by/4.0/legalcode

Vol. 1(4) 2012, Pg. 24 - 33

http://hrmars.com/index.php/pages/detail/IJARPED

JOURNAL HOMEPAGE

Full Terms \& Conditions of access and use can be found at http://hrmars.com/index.php/pages/detail/publication-ethics 


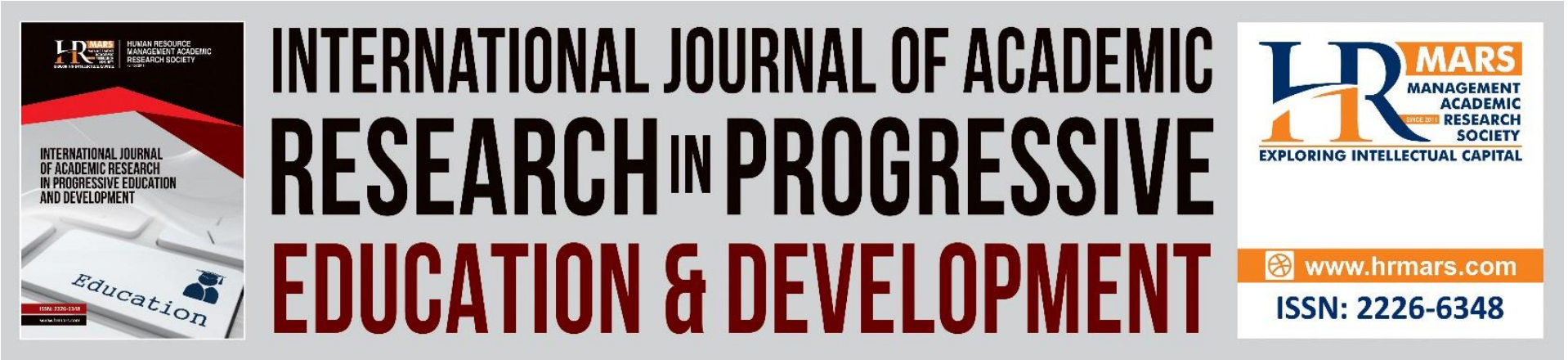

\title{
Evaluation of Academic Staff Development Practices Outcomes on Job Performance in Selected Public Universities in Kenya
}

\author{
Jane Irene A. Dawo, Simatwa Enose, M. W., Okwatch Tony, O. \\ Maseno University, Dept of Education Management and Foundations, P.O. Box 333 Maseno, \\ Kenya \\ Email: dawojanei@gmail.com
}

\begin{abstract}
Academic staff development enhances job performance among PhD degree holders in public universities in Kenya. However, it is noteworthy that at Maseno University and Masinde Muliro University of Science and Technology, Kenya's youngest, most recently established universities, only an average of $38 \%$ of academic staff are $\mathrm{PhD}$ degree holders indicating a skills, knowledge, and attitudinal gap hence a critical need for invigorated staff development. In addition, there is a high lecturer: student ratio which is above the Commission for Higher Education's recommendation of 1:18 for social sciences and 1:10 for pure sciences. There have also been incessant public complaints about poor job performance evidenced in poor lecturer etiquette, low lesson attendance levels, relative high failure rates among students and non-return of Continuous Assessment Tests. The purpose of this study was to evaluate the outcomes of selected academic staff development practices on job performance in selected public universities. The selected staff development practices are categorized as follows; on-the-job-university-sponsored, off-the-job-self-sponsored, off-the-job-universitysponsored, and on-the-job-self-sponsored. The study employed descriptive survey research design whereby questionnaire, document analysis, and interview schedules were used to collect data. Proportional Stratified Random Sampling and Purposive Sampling technique was used to select academic staff, Chahairmen of Departments (CoDs) and Directors of Faculties and Deans of Schools (DFDSs) in the selected universities. Quantitative data was presented in frequencies, percentages, and Mean Rating. Qualitative data was analyzed on an going process as themes and subthemes emerged.
\end{abstract}

Keywords: Staff Development Practices, Academic Staff, University, PHD Degree, Kenya

\section{Background to The Study}

Staff development is becoming increasingly important as organizations attempt to maintain competitiveness and productivity having recognized career management as a component of strategic human capital formation in dynamic environments (King, 2003). It removes performance deficiencies, to retrain displaced workers, to train in workplace safety, to develop management personnel, and for career development (Quick \& Nelson, 2011). 
In an educational institution, in-service teaching staff development, aims at improving capacities of individuals to play their roles and fit in assignments optimally for higher achievements resulting from quality service delivery. The programme foci may include classroom management, lesson organization, recording and reporting students work achievement on assessable and acquired for-life standards, teaching skills, teacher behaviour, teacher administration, material resource management, student management and so on (Jamil et al., 2011). It therefore follows that, improvement of teaching staff competence is crucial to attain quality university education.

With regard to university education, Ministry of Education Strategic Plan 2006-2011 focuses on expanded access to education, affirmative action, improved infrastructure, and rationalization of academic programmes downplaying teaching staff development (Republic of Kenya, 2005). Staff quality is invaluable particularly in the prevailing circumstances whereby Kenya is pursuing a new scientific techno-economic development strategy, Vision 2030 (Kairu, 2011). On the whole, university is the pinnacle of education in Kenya, training manpower vital for the economic, social and political pillars of Vision 2030 (Republic of Kenya, 2007), yet apart from addressing access, unlike that of teaching staff training at lower levels, there is no focus on university staff development. Therefore, it becomes critical for individual university managements to fill policy-strategy gaps at the national level by instituting appropriate measures locally, so as to contribute effectively to Vision 2030.

A study by Makawiti (2011) on perceptions of academic staff in Kenyan public universities on application of performance appraisal results in training and promotion decisions revealed that $47.4 \%$ of academic staff believed that there was a training policy in place but probably could not have been related to performance appraisal results. He asserted that if well designed, staff development programmes in public universities could help foster employee commitment. This was a cross-sectional survey design in which questionnaire, in-depth interview and document analysis was used to collect data from Human Resource Managers and academic staff. It was analyzed using correlation analysis. This differs with the current study which aims at determining the impact of staff development practices on job performance in selected public universities.

Unfortunately, Commission for Higher Education ( $\mathrm{CHE}$ ) is preoccupied with accreditation of private universities ignoring other vital functions among them staff scholarship. The chairman of the CHE has lamented that the situation of quality of faculty staff in universities whereby nationally, less than $8 \%$ of the permanent teaching staff are professors, indicates an appalling shortage of mentors and teachers for junior staff. This is besides the fact that all staff, inclusive of professors, require rejuvenated staff development programs (Kairu, 2011).

There seems to be a general agreement that training and development is a good thing and it causes productivity but the question is "How much?" It is even difficult to show a causal link between the human capital development and organizational performance partly because its pay-off may not be seen in the short term (Torrington et al., 2005). However, according to Eyopuglu \& Sanner (2009), in a university setting, opportunities for training and development may be considered to be a reward when promotion or salary upgrade is less available. On this note, Gudo, et al (2011) recommends structured staff development programmes grounded in educational vision. 
Continuing staff development is vital to suit the changing work environment which renders obsolete some of their original professional skills and knowledge. Oyoo \& Bwoga (2009) carried out a study on post graduate students' perspective of an exemplary teacher and found that a teacher with competencies such as; work planning, classroom practices, classroom management and personal viewpoints scored highly. This would all be enhanced through inservice courses. Ockae-Anti (2007) studied the impact of in-service training on non-teaching staff at University of Education, Ghana. He used questionnaire and interviews and found that it enhanced job performance as well as career development. This differs with the current study which focused on academic staff.

Through staff training and development, employees offer high productivity and total commitment while their employers' offers enhanced employability rather than long- term employment (Aguinis, 2007).There arises a new psychological contract in which the deal between the employer and staff is different but still mutually beneficial. It enables workers to develop skills and experiences that are in demand and allows them opportunities to keep updated ready to obtain another appropriate job when no longer needed by their present employer (Werner et al, 2006). Unlike the aforementioned, this study focused on the effect of academic staff development practices in a university on job performance at selected public universities.

\section{Justification for The Study}

Modern organizations emphasize on staff development as a strategic human resource management to remove performance deficiencies and align its employees to the ever dynamic work-place demands. Universities in Kenya are not an exception and so they are spending colossal amounts of money sourced both internally and externally to train its academic staff. However, there are complaints that they still exhibit certain characteristics that are indicative of poor job performance such as poor content delivery, poor lecturer etiquette, and unavailability for consultation. This necessitates an evaluation of the various academic staff development practices used by these institutions to train its PhD staff and their outcomes on actual teaching activity job performance.

\section{Results and Discussion}

The study sought to comparatively rate the influence of selected staff development practices on job performance by considering specific categories of expected work to be performed by $\mathrm{PhD}$ academic staff in selected universities. The area of focus is Actual Teaching Activity grounded on some observable aspects of teaching in a structured Likert Scale.

\section{Actual Teaching Activity}

With regard to Actual teaching activity, PhD staff who had undergone the varied staff development practices responded as shown in Tables 4.8.1, 4.8.2, 4.8.3 and 4.8.4. 
Table 4.8.1 Responses from PhD on-the-job-university-sponsored Respondents

\begin{tabular}{|c|c|c|c|c|c|c|c|}
\hline \multirow[t]{2}{*}{ Job Performance Indicators } & \multicolumn{5}{|c|}{ Response } & \multirow[b]{2}{*}{ Total } & \multirow[t]{2}{*}{ MR } \\
\hline & VR & RA & $\mathbf{N}$ & $\mathbf{R E}$ & VE & & \\
\hline $\begin{array}{l}\text { I give course outlines to } \\
\text { students on time }\end{array}$ & 3 & 23 & 13 & 8 & 2 & 130 & 2.65 \\
\hline $\begin{array}{l}\text { I recommend/ give reading } \\
\text { materials to students }\end{array}$ & 3 & 24 & 18 & 5 & 0 & 124 & 2.53 \\
\hline I go to class in time/ punctuality & 0 & 02 & 29 & 14 & 4 & 138 & 2.81 \\
\hline $\begin{array}{l}\text { I allow students to participate } \\
\text { actively during my teaching }\end{array}$ & 3 & 20 & 24 & 02 & 0 & 123 & 2.51 \\
\hline $\begin{array}{l}\text { I give feedback of CATs in time / } \\
\text { as expected }\end{array}$ & 11 & 18 & 15 & 5 & 0 & 111 & 2.28 \\
\hline Average & & & & & & & 2.55 \\
\hline
\end{tabular}

Key: VR- Very Rarely RA Rarely N- Neutral

RE - Regularly VE - Very Regularly T- Total MR- mean Rating

Table 4.8.2 Responses from PhD off-the-job-self sponsored respondents $n=33$

\begin{tabular}{|c|c|c|c|c|c|c|c|}
\hline \multirow[t]{2}{*}{ Job performance indicators } & \multicolumn{5}{|c|}{ Response } & \multirow[b]{2}{*}{$\mathbf{T}$} & \multirow[t]{2}{*}{ MR } \\
\hline & VR & RA & $\mathbf{N}$ & $\mathbf{R E}$ & VE & & \\
\hline $\begin{array}{l}\text { I give course outlines to } \\
\text { students in time }\end{array}$ & 0 & 15 & 15 & 3 & 0 & 87 & 2.63 \\
\hline $\begin{array}{l}\text { I recommend/ give reading } \\
\text { materials to students }\end{array}$ & 0 & 6 & 13 & 14 & 0 & 107 & 2.26 \\
\hline I go to class in time/punctuality & 0 & 5 & 21 & 5 & 2 & 103 & 3.12 \\
\hline $\begin{array}{l}\text { I allow students to participate } \\
\text { actively during my teaching }\end{array}$ & 0 & 5 & 27 & 1 & 0 & 95 & 3.87 \\
\hline $\begin{array}{l}\text { I give feedback of CATs in time/ } \\
\text { as expected }\end{array}$ & 0 & 11 & 18 & 2 & 2 & 94 & 2.84 \\
\hline Average & & & & & & & 2.94 \\
\hline VR- Very Rarely & & & & & & & \\
\hline
\end{tabular}


Table 4.8.3 Responses from PhD on-the-job-self -sponsored respondents $n=23$

\begin{tabular}{|c|c|c|c|c|c|c|c|}
\hline \multirow[t]{2}{*}{ Job performance indicators } & \multicolumn{5}{|c|}{ Response } & \multirow[b]{2}{*}{$\mathbf{T}$} & \multirow[t]{2}{*}{ MR } \\
\hline & VR & RA & $\mathbf{N}$ & RE & VE & & \\
\hline $\begin{array}{l}\text { I give course outlines to } \\
\text { students in time }\end{array}$ & 0 & 4 & 12 & 7 & 0 & 72 & 3.13 \\
\hline $\begin{array}{l}\text { I give/ recommend reading } \\
\text { materials to students }\end{array}$ & 0 & 7 & 9 & 3 & 4 & 73 & 3.17 \\
\hline I go to class in time/ punctuality & 0 & 1 & 19 & 2 & 1 & 72 & 3.13 \\
\hline $\begin{array}{l}\text { I allow students to participate } \\
\text { actively during my teaching }\end{array}$ & 2 & 9 & 10 & 2 & 0 & 58 & 2.52 \\
\hline $\begin{array}{l}\text { I give feedback of CATs in time/ } \\
\text { as expected }\end{array}$ & 2 & 10 & 8 & 3 & 0 & 58 & 2.52 \\
\hline Average & & & & & & & 2.89 \\
\hline $\begin{array}{l}\text { VR- Very Rarely RA Rarely } \\
\text { RE - Regularly VE - Very Regular }\end{array}$ & T & & $\begin{array}{l}\mathrm{N}-1 \\
\mathrm{MR}\end{array}$ & 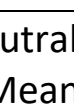 & & & \\
\hline
\end{tabular}

Table 4.8.4 Responses from PhD off-the-job-university -sponsored Respondents $n=44$

\begin{tabular}{|c|c|c|c|c|c|c|c|}
\hline \multirow[t]{2}{*}{ Job performance indicators } & \multicolumn{4}{|c|}{ Response } & \multirow[b]{2}{*}{ VE } & & \multirow[t]{2}{*}{ MR } \\
\hline & VR & $\mathbf{R A}$ & $\mathbf{N}$ & RE & & $T$ & \\
\hline $\begin{array}{l}\text { I give course outlines to } \\
\text { students in time }\end{array}$ & 0 & 5 & 21 & 15 & 3 & 148 & $\begin{array}{l}2.9 \\
6\end{array}$ \\
\hline $\begin{array}{l}\text { I give/ recommend reading } \\
\text { materials to students }\end{array}$ & 0 & 9 & 20 & 15 & 0 & 138 & $\begin{array}{l}3.1 \\
3\end{array}$ \\
\hline I go to class in time/punctuality & 0 & 4 & 30 & 8 & 2 & 140 & $\begin{array}{l}3.1 \\
8\end{array}$ \\
\hline $\begin{array}{l}\text { I allow students to participate } \\
\text { actively during my teaching }\end{array}$ & 0 & 13 & 18 & 12 & 0 & 128 & $\begin{array}{l}2.9 \\
0\end{array}$ \\
\hline $\begin{array}{l}\text { I give feedback of CATs in time/ } \\
\text { as expected }\end{array}$ & 4 & 11 & 17 & 12 & 0 & 125 & $\begin{array}{l}2.8 \\
4\end{array}$ \\
\hline Average & & & & & & & $\begin{array}{l}3.0 \\
0\end{array}$ \\
\hline
\end{tabular}

\begin{tabular}{llcl}
\hline Key: & VR- Very Rarely & RA Rarely & N- Neutral \\
& RE - Regularly VE - Very Regularly T- Total & MR- Mean Rating
\end{tabular}

With regard to actual teaching activity, the respondents were exposed to a predesigned Likert Scale from which the responses were Mean Rated and ranked as follows:

1. Off-the-job-university-sponsored $(n=44)-3.00$

2. Off-the-job-self-sponsored( $n=33)-\quad 2.94$

3. On-the-job-self-sponsored( $n=23)-\quad 2.89$

4. On-the-job-university-sponsored(n=49)- 2.55

The difference in Mean Rating from the highest at 3.17 to the lowest at 2.55 is 0.45 which is statistically insignificant.

In a review of 310 studies in 1980, it was found that the structure of teacher education had changed very little leaning towards reinforcing transmission, or rather passive models of 
learning. As reported by Amalia \& Fotopoulus (2011) it therefore had minimal impact in subsequent classroom instruction, hence in Greece, only $9 \%$ of these in-service staff development programmes have statistically significant influence on student performance. This seems to be in agreement with this study whereby following PhD staff development of academic staff, the variability between the different staff development practices is only 0.45 , arguably, a statistically insignificant amount. However, the minimal positive change realized would be in agreement with Out(2011) that Staff development positively impact on learning.

Ralph (2003) cited in Axelrod (2008) identified 5 criterion upon which quality teaching can be judged. These were; commitment to learners, knowledge of material, organization and management of the environment, desire to improve, and collaboration. He concluded that exemplary university teaching is discernable, and the quality can be assessed using Likert Scales. This was confirmed by Axelrod (2008) who conducted such a survey in February 2008 and April 2008 whereby the responses remained the same. Based on this position, this study used Likert scales for academic staff self-report to find out whether they thought they had improved in performance following PhD staff development.

Teaching is incomplete without considering the leaner aspect since it is easy to gauge validity of instruction from the perspective of the consumer, the students. According to Goer, Bell and Little(2008) in a survey of 12 strategies to measure teaching effectiveness, students were better judges of faculty effectiveness since they could assess the following:

i. Their increased knowledge and comprehension

ii. Perceived changes in motivation towards subject taught

iii. Observed teacher behaviour relevant to competent teaching such as punctuality

iv. Student consumerism; information not relevant to competent teaching but important to students such as class attendance policy, homework, and text book costs.

In this study, the impracticality of using students to evaluate PhD academic staff stems from the fact that there is high likelihood that the cohort handled by an academic staff before the commencement of his PhD programme is likely to have graduated by the time he completes the staff development programme. They will therefore not be available to experience the 2 teaching scenarios so as to make comparison, more so since the period of inception of MSU in 1990 and MMUST in 2002. Besides, as reported in Goer et al(2008), there have been signs of faculty hostility and cynicism towards student ratings and hence the conclusion that even this method is not fool proof. It would also be unreasonable to expect students to be informed about which of their academic staff pursued their PhD while already in teaching employment at MSU and MMUST. It can therefore be concluded that even though self evaluation has a myriad of limitations, for the study circumstances, it was the most plausible approach.

It was also important to note that as revealed by 23(53\%) of the CoDs staff making judgment on value addition on PhD staff is not a simple task. This is because after graduating with a $\mathrm{PhD}$, they perform tasks unique to the new status such as supervision and teaching of Masters degree and PhD students alongside belonging to other boards and committees which they could not access without PhD. In this respect, $1(2 \%)$ CoDs were in agreement with $3(30 \%)$ 
DFDS that for the evaluation to be objective, then these PhD graduates may be considered in cohorts, impossibility.

This was against the argument by $1(2 \%)$ on-the-job-university sponsored respondent who said that even if the PhD staff were bundled in cohorts or based on staff development practices, date of graduation, faculties or departments, there are still some inherent differences within and between them that make it practically impossible to compare PhD academic staff job performance objectively. How would one compare the performance of a lecturer supervising project work with one supervising thesis or lecturers teaching the same course in different universities when students do not sit a common examination? From the above, it can be said that evaluation is based merely on perception.

Respondents were asked whether they knew about an institutional staff development policy. This was confirmed by its availability on respective university websites. Out of the academic staff who had undergone PhD staff development while working at their current universities of employment, 149(100\%) were aware of its existence in their university, 102(68\%) thought that it was being implemented as stipulated, 63(42\%) believed they had benefited from its implementation, while $41(28 \%)$ were of the view that they had been disadvantaged following its implementation.131(88\%) of academic staff were of the view that their perception of staff development policy had an influence on how they performed their jobs. Asked whether they thought their out put was commensurate with the input in PhD staff development, $115(77 \%)$ disagreed. Instead, they thought that other factors such improved salaries, recognition and promotion were driving staff to work better. As reported by $50(34 \%)$, in the absence of the above, they would not offer their services with commitment because people just don't undergo staff development for the sake of it. It was therefore necessary for university managements to revitalize academic staff appraisal systems for improved job performance (Makawiti, 2011).

The study revealed that $118(79 \%)$ of the respondents had been promoted by at least by one job grade since they attained their $\mathrm{PhD}$ to positions such as lecturer, senior lecturer, associate professor, and professor. It was also realized that earlier PhD graduation dates were generally supported by promotion to higher echelons in the university set up. There was no distinction or clear cut categorization as regards promotion in relation to the staff development practice academic staff had undergone. Asked about what they thought led to their promotion or lack of it, the $79 \%$ who had been promoted indicated so; $29(19 \%)$ their attainment of a PhD, $62(41 \%)$ their job performance, and $27(18 \%)$ availability of opportunity for upward mobility. The remaining 31(21\%) who had not been promoted following their attainment of PhD noted that it was because of $11(7 \%)$ favouritism, and $20(14 \%)$ lack of clear career development structures in the university.

\section{Conclusions and Recommendations}

Universities have staff development policies that are documented but majority of the staff cannot attest to their effectiveness or, and their implementation as a basis for their PhD academic staff development programmes. There is no significant difference in job performance based on the selected academic staff development practices in public universities as revealed in the self-report. Staff development parse does not lead to significant improvement in job performance if not supported with other career development strategies 
such as recognition, promotion, and salary increase. There are no clear and staff appraisal structures in these universities.

Universities should use other motivational strategies alongside staff development to engineer staff interest for improved job performance. Such may include reward, recognition, or promotion. There should be well designed staff appraisal procedures to evaluate staff as well as inspire further improvement in performance.

\section{Suggestions for Further Research}

This study used likert scale for self-evaluation to gauge performance of PhD academic staff in a cross sectional survey in a structured questionnaire. This may be prone to biasness in respondents and so alternative research methodologies may be used to pursue in-depth understanding of the causal relationship. These approaches may include triangulation of case studies and longitudinal research designs. Such studies may include vital demographic considerations such as gender, experience in years of teaching in university, and job grades.

\section{References}

Aguinis, H. (2007). Performance Management. Prentice hall, London.

Amalia, I., \& Fotopoulopou, U. S. (2011). Teachers' Perception of Professionalism and Professional Development: A Case Study in Greece. World Journal of Education. Vol. 1, April 2011.

Axelrod, P. (2008). Student Perspectives on Good Teaching: What History Reveals- Academic Matters. The Journal of Higher Education 24(227) Retrieved 13-10-2011 at 6 pm. http:/www.ocufa.on.ca/AM-Feb08/Feb08p24.

Eyopuglu, S. Z., \& Sanner, T. (2009). The Relationship Between Job Satisfaction and Academic Rank: A Study of Academicians in Northern Cyprus. Paper Presented at a World Conference on Educational Sciences, North Cyprus, February 4th -7th.

Goer, L. G., Bell, C., \& Little, O. (2008). Approaches to Evaluating Teacher Effectiveness: A Research Synthesis. Comprehensive Centre for Teacher Quality. Washington DC

Gudo, C. O., Oanda, I. O., \& Olel, M. A. (2011). Role of Institutional Managers in Quality Assurance: Reflections on Kenya's University Education. Australian Journal of Business and Management Research. Vol 1(2) 113-124.

Jamil, A., Atta, A. M., Ali, V., Balochi, J., \& Ayaz, M. (2011). Effects of in-service Training in Meliorating Teachers' Performance at Secondary School level International Journal of Academic Research vol.3 (2) 624-628

Kairu, P. (2011). The Fall and Fall of University Education Standards in Kenya. Daily Nation Daily Kenya Living pp. 1-3

King, Z. (2003). New or Traditional Careers? A Study of UK Graduates Perceptions Human Resource Management Journal. Vol. 13 No. 1, 5-6.

Makawiti, D. W. (2011). Perception of Academic Staff in Kenyan Public Universities Towards Application of Performance Appraissal Results in Training and Promotion Decisions. Unpublished MBA Project, University of Nairobi.

Ockae-Anti, C. (2007). An Assessment of the Impact of In-service Training on Staff Performance at University of Education, Winnebe Campus, Ghana. International Journal of Education Research. Vol. 3(2) 217-224.

Out, J. A. (2011). Teachers in Ghana: Issues of Training, Remuneration and Effectiveness. International Journal of Educational Development, 26(1), 38-51. 
Oyoo, S. O., \& Bwoga, P. O. (2009). Post Graduate Students' Perspective of an Exemplary Teacher. The International Journal of Learning Vol.16(6)43-64.

Republic of Kenya. (2005). Ministry of Education Strategic Plan 2006-2011. www.education.go.ke. Retrieved 2/10/2011 at 10.10 am.

Republic of Kenya. (2007). Vision 2030 Blue Print. Nairobi: Ministry of State, Planning and National Development, Kenya.

Werner, J., Randy, L., \& Le Desimone, R. (2006) Human Resource Development. South Western Centage, London: CIPD. 